\title{
Rancang Bangun Aplikasi Doremi sebagai Pengenalan Alat Musik Berbasis Android dengan Metode User Centered Design
}

\author{
Lia Ayu Kusumaningrum ${ }^{1}$,Febrian Murti Dewanto ${ }^{2}$, Aris tri Jaka Harjanta ${ }^{3}$ \\ Prodi Informatika, Universitas PGRI Semarang \\ Jalan Sidodadi Timur No. 24 Semarang \\ 1*liaayuka@gmail.com, ${ }^{2}$ fmdewanto@gmial.com, ${ }^{3}$ aristrijaka@gmail.com
}

\begin{abstract}
Abstrak
Pendidikan musik memiliki banyak manfaat dalam perkembangan kemampuan seorang anak, salah satunya adalah membantu meningkatkan konsentrasi dan imajinasi anak. Saat ini banyak orang tua yang mulai menyadari bahwa mengenalkan musik pada anak sejak usia dini adalah hal yang penting. Orang tuapun mulai mengajari alat musik secara langsung maupun melalui digital pada anak. Namun aplikasi yang ada saat ini belum memenuhi keinginan dan ketertarikan bagi pengguna. Maka, diberikan solusi rancang bangun aplikasi pengenalan alat musik bernama DOREMI dengan menggunakan metode User Centered Design (UCD). Perancangan aplikasi DOREMI berbasis Android ini memperhatikan banyak aspek. Salah satu aspek paling penting dalam perancangan aplikasi Android ini yaitu desain User Interface dan User Experience (UI/UX). Dengan perancangan UI/UX yang menarik akan menimbulkan minat pada anak-anak untuk belajar alat musik dari aplikasi tersebut. User Interface fokus kepada bagaimana seluruh tampilan aplikasi Android dilihat dan ditata dari antarmuka dengan pengguna. Sedangkan User Experience fokus kepada kenyamanan pengguna saat menggunakan aplikasi. Kemudian aplikasi diuji menggunakan white box dan black box.
\end{abstract}

Kata kunci: Musik, Aplikasi, Android, Digital

\section{PENDAHULUAN}

Membangun karakter merupakan bagian dari pola pendidikan anak agar anak tak hanya memiliki kecerdasan kognitif (pengetahuan), tetapi juga memiliki kecerdasan afektif (emosional) yang seimbang. Salah satu cara untuk membangun karakter anak adalah melalui pendidikan musik. Pendidikan musik memiliki banyak manfaat dalam perkembangan seorang anak, salah satunya adalah membantu merangsang perkembangan kemampuan meningkatkan konsentrasi, mengembangkan daya persepsi, dan imajinasi anak (Oktafiani, 2014).

Saat ini banyak orang tua mulai menyadari untuk mengenalkan musik pada anak sejak usia dini. Hal ini terbukti tumbuhnya berbagai kursus musik yang merupakan bagian dari jawaban akan besarnya animo masyarakat mengenai pentingnya mengenalkan musik pada anak sejak usia dini. Kesadaran ini diyakini karena adanya penelitian tentang musik, terutama musik klasik ternyata sangat mempengaruhi perkembangan IQ (Intelegent Quotient) dan EQ (Emotional Quotient). Anakanak yang sejak kecil terbiasa bergaul dan mendengarkan musik akan memiliki kecerdasan emosional dan intelegensi yang lebih berkembang, dibandingkan anak-anak yang yang jarang mendengarkan musik. Dalam hal kedisiplinan juga demikian, biasanya anak yang sering mendengarkan musik akan jauh lebih disiplin daripada yang tidak (Izzaty, 2013).

Pada era yang modern, ilmu pengetahuan dan teknologi semakin berkembang pesat baik teknologi informasi maupun teknologi komunikasi seperti android. Aplikasi berbasis android menjadi salah satu teknologi yang kini telah banyak digunakan untuk membantu kemudahan manusia di beberapa bidang dalam kehidupan seperti jejaring sosial, hiburan, dan juga pendidikan. Dalam dunia pendidikan aplikasi pembelajaran berbasis android bisa diakses kapan dan di mana saja, tanpa batasan dalam memperoleh informasi mengenai pedidikan, sebab pendidikan merupakan faktor yang penting dalam membentuk individu yang berkualitas, termasuk salah satunya adalah pendidikan untuk pengenalan alat alat musik (Ardiansyah dan Sadikin, 2018).

Dengan pemanfaatan teknologi, pengenalan alat-alat musik dapat dilakukan melalui sebuah aplikasi. Namun aplikasi yang ditemukan saat ini cenderung kurang memperhatikan keinginan dan ketertarikan bagi pengguna. Selain menampilkan informasi, 
aplikasi seharusnya memiliki perencanaan desain antarmuka yang baik. Sehingga pengguna dapat berinteraksi dengan antarmuka aplikasi secara nyaman. Oleh karena itu, perlu memperhatikan desain User Interface dan User Experience (UI/UX) untuk membuat aplikasi yang mudah digunakan atau user friendly.

UCD (User Centered Design) adalah filosofi perancangan yang menempatkan pengguna sebagai pusat dari proses pengembangan sistem. Pendekatan UCD telah didukung berbagai teknik, metode, tools, prosedur, dan proses yang membantu perancangan sistem interaktif yang lebih berpusat pada pengguna. Sasaran UCD adalah lebih dari sekedar membuat produk yang berguna (Amborowati,2010).

Peneliti melakukan studi tinjauan pustaka melalui perbandingan beberapa aplikasi yang berhubungan dengan pengenalan alat musik. Perbandingan ini berdasarkan pada kriteria yang diinginkan pengguna.

Tabel 1. Perbandingan Antar Aplikasi Serupa

\begin{tabular}{lcccc}
\hline \multirow{2}{*}{ Produk } & \multicolumn{4}{c}{$\begin{array}{c}\text { Kriteria yang diinginkan } \\
\text { pengguna }\end{array}$} \\
\cline { 2 - 5 } & $\begin{array}{c}\text { Basis } \\
\text { Android }\end{array}$ & Kreatif Simpel & Visual \\
\hline $\begin{array}{l}\text { Mengenal } \\
\text { Musik }\end{array}$ & $\mathrm{v}$ & - & $\mathrm{v}$ & - \\
$\begin{array}{l}\text { Alat Musik } \\
\text { Anak-Anak }\end{array}$ & $\mathrm{v}$ & $\mathrm{v}$ & - & - \\
Alat Musik & $\mathrm{v}$ & $\mathrm{v}$ & - & $\mathrm{v}$ \\
$\begin{array}{l}\text { Bayi } \\
\text { Yuk Kenali } \\
\text { Alat Musik }\end{array}$ & - & - & $\mathrm{v}$ & - \\
\hline
\end{tabular}

Dapat disimpulkan bahwa aplikasi yang ada belum memenuhi keinginan dan ketertarikan pengguna. Sehingga diperlukan perancangan aplikasi dengan metode UCD. Sehingga perancangan aplikasi menempatkan pengguna sebagai pusat dari proses pengembangan sistem. Berikut ini disajikan melalui tabel pembanding penelitian terdahulu dengan metode UCD sebagai berikut:

Tabel 2. Perbandingan penelitian dengan metode UCD

\begin{tabular}{llcl}
\hline Sumber & Topik & $\begin{array}{c}\text { Observasi } \\
\text { Data }\end{array}$ & $\begin{array}{c}\text { Bahasa } \\
\text { Pemrograman }\end{array}$ \\
\hline Armadyah, & Sistem & Wawancara & Web (PHP) \\
Amborowati Pameran & & \\
Online & &
\end{tabular}

\begin{tabular}{|c|c|c|c|}
\hline Sumber & Topik & $\begin{array}{c}\text { Observasi } \\
\text { Data }\end{array}$ & $\begin{array}{c}\text { Bahasa } \\
\text { Pemrograman }\end{array}$ \\
\hline Dini Pratiwi & $\begin{array}{l}\text { Rancang } \\
\text { Ulang Web } \\
\text { Portal } \\
\text { Jurusan } \\
\text { Psikologi } \\
\text { FISIP } \\
\text { Universitas } \\
\text { Brawijaya }\end{array}$ & $\begin{array}{c}\text { Wawancara } \\
\text { dan } \\
\text { Kuesioner }\end{array}$ & Web (PHP) \\
\hline $\begin{array}{l}\text { Dwi Yuli } \\
\text { Haryanto }\end{array}$ & $\begin{array}{l}\text { Pemesanan } \\
\text { Barang }\end{array}$ & Wawancara & Android \\
\hline $\begin{array}{l}\text { Samsu Rizal } \\
\text { Ibnu }\end{array}$ & $\begin{array}{l}\text { Wisata } \\
\text { Kuliner }\end{array}$ & Kuesioner & Android \\
\hline
\end{tabular}

Pada Sistem Pameran Online diperoleh hasil penelitian dengan menggunakan metode UCD untuk perancangan sistem, sistem yang dihasilkan menjadi lebih memberikan kepuasan bagi user dan meningkatkan kemanfaatan sistem tersebut (Amborowati, 2010). Kemudian pada Rancang Ulang Web Portal Jurusan Psikologi FISIP Universitas Brawijaya dengan menggunakan metode UCD hasil evaluasi desain solusi mengalami kenaikan di setiap atribut yang ada dibandingkan dengan hasil evaluasi sebelumnya (Pratiwi dkk, 2018). Pada aplikasi Pemesanan Barang menggunakan Metode User Centered Design (UCD) Berbasis Android, kegiatan pemesanan lebih efektif dan efisien (Haryanto, 2013). Sedangkan pada aplikasi Wisata Kuliner, Metode UCD dapat membantu perancangan aplikasi berbasis Android ini dengan memprioritaskan kebutuhan dan kenyamanan pengguna (Khasani. 2017).

Berdasarkan penelitian tersebut di atas, maka peneliti melakukan rancang bangun Aplikasi DOREMI sebagai pengenalan alat-alat musik menggunakan metode UCD. Sehingga, dengan penerapan metode UCD diharapkan aplikasi ini dapat meningkatkan kemanfaatan dan menarik bagi pengguna.

\section{TINJAUAN PUSTAKA}

\subsection{Aplikasi}

Perangkat lunak aplikasi adalah suatu subkelas perangkat lunak komputer yang memanfaatkan kemampuan komputer langsung untuk melakukan suatu tugas yang diinginkan pengguna. Biasanya dibandingkan dengan perangkat lunak sistem yang mengintegrasikan berbagai kemampuan komputer, tapi tidak secara langsung menerapkan kemampuan tersebut untuk mengerjakan suatu tugas yang menguntungkan pengguna. 


\subsection{Android}

Android adalah sistem operasi berbasis Linux bagi telepon seluler seperti telepon pintar dan komputer tablet. Android juga menyediakan platform terbuka bagi para pengembang untuk menciptakan aplikasi mereka sendiri yang akan digunakan untuk berbagai macam piranti gerak (Safaat, 2012).

\subsection{Metode User Centered Design}

Metode User Centered Design (UCD) yaitu metode konsep desain antarmuka yang berpusat pada pengguna dengan penarikan kesimpulan dari pengalaman pengguna melalui observasi secara efisien. Proses desain antarmuka lebih fokus pada tujuan kegunaan, karakteristik pengguna, tugas, dan alur kerja dalam desain antarmuka. Semua informasi yang didapatkan melalui analisa dari kebiasaan melalui sebuah survei. Hasil analisa kemudian diolah sehingga didapat keputusan perancangan desain antarmuka yang user friendly (Garret, 2011).

Dalam metode UCD digunakan tahapan dengan melakukan aktivitas sebagai berikut:

1. Survei Kuesioner atau Wawancara

2. Task Modelling

3. Prototyping

\subsection{Unified Modelling Language (UML)}

Pada teknik perancangan berdasarkan objek oriented, hasil pemodelan konseptual digunakan untuk menggambarkan fungsionalitas sesuai persyaratan yang ditentukan pelanggan. Pemodelan konseptual itu diwujudkan dalam bentuk sebuah standar untuk merancang model sebuah sistem yang bernama Unified Modelling Language (UML)

\subsection{Software Testing}

Pengujian perangkat lunak atau software testing adalah satu set aktivitas yang direncanakan dan sistematis untuk menguji atau mengevaluasi kebenaran yang diinginkan. Pengujian terhadap perangkat lunak dilakukan untuk menghindari banyaknya kesalahan. Pengujian perangkat lunak tidak hanya dilakukan untuk meminimalisir kesalahan secara teknik tetapi juga kesalahan non teknis. Kesalahan non teknis tersebut seperti pengujian pesan kesalahan sehingga user tidak bingung (Sukamto dan Shalahudin, 2011).

\section{METODE PENELITIAN}

Langkah-langkah yang akan dilakukan untuk melakukan penelitian ini yaitu sebagai berikut :

1. Mempelajari data-data yang akan digunakan serta mempelajari User Centered Design (UCD).

2. Mengumpulkan data yang dibutuhkan untuk diproses.

3. Mempersiapkan alat dan bahan penelitian.

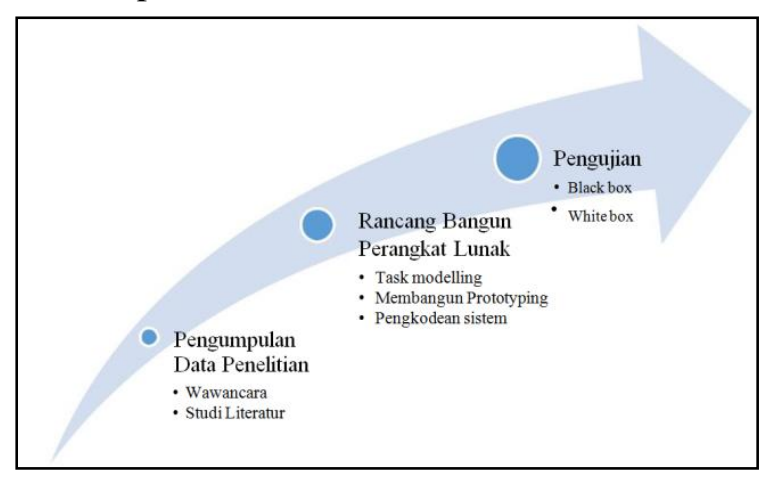

Gambar 1. Skema Penelitian

\section{HASIL DAN PEMBAHASAN}

Spesifikasi kebutuhan pengguna diketahui melalui wawancara kepada 5 orang tua yang memiliki anak usia 2-6 tahun yang pernah menggunakan aplikasi pengenalan alat musik sebelumnya.

Tabel 3. Hasil Wawancara

\begin{tabular}{|c|c|c|}
\hline Hasil & $\begin{array}{c}\text { Respon } \\
\text { den }\end{array}$ & Hasil Respon \\
\hline \multirow[t]{5}{*}{$\begin{array}{l}\text { Wawancara } 1 \\
\text { (Tujuan } \\
\text { penggunaan) }\end{array}$} & 1 & $\begin{array}{l}\text { Mengenalkan alat musik } \\
\text { pada anak dan sebagai } \\
\text { hiburan }\end{array}$ \\
\hline & 2 & $\begin{array}{l}\text { Mengenalkan alat musik } \\
\text { pada anak dan mengisi } \\
\text { waktu luang anak }\end{array}$ \\
\hline & 3 & $\begin{array}{l}\text { Mengenalkan alat musik } \\
\text { pada anak }\end{array}$ \\
\hline & 4 & $\begin{array}{l}\text { Mengenalkan alat musik } \\
\text { pada anak }\end{array}$ \\
\hline & 5 & $\begin{array}{l}\text { Mengenalkan alat musik } \\
\text { pada anak }\end{array}$ \\
\hline \multirow{3}{*}{$\begin{array}{l}\text { Wawancara } 2 \\
\text { (Kendala } \\
\text { aplikasi } \\
\text { sebelumnya) }\end{array}$} & 1 & $\begin{array}{l}\text { Aplikasi hanya dapat } \\
\text { digunakan di PC }\end{array}$ \\
\hline & 2 & $\begin{array}{l}\text { Backsound mengganggu } \\
\text { fokus anak }\end{array}$ \\
\hline & 3 & $\begin{array}{l}\text { Desain yang kurang } \\
\text { menarik untuk anak }\end{array}$ \\
\hline
\end{tabular}




\begin{tabular}{rcl}
\hline Hasil & $\begin{array}{c}\text { Respon } \\
\text { den }\end{array}$ & \multicolumn{1}{c}{ Hasil Respon } \\
\hline 4 & $\begin{array}{l}\text { Banyak menu yang tidak } \\
\text { perlu }\end{array}$ \\
5 & $\begin{array}{l}\text { Suara alat musik terlalu } \\
\text { panjang dan tidak dapat } \\
\text { dipilih acak }\end{array}$ \\
\hline
\end{tabular}

\begin{tabular}{lll}
\hline $\begin{array}{l}\text { Wawancara 3 } \\
\text { (Keinginan } \\
\text { pengguna) }\end{array}$ & 1 & $\begin{array}{l}\text { Aplikasi berbasis } \\
\text { android tapi mudah } \\
\text { Tidak terdapat } \\
\text { backsound yang } \\
\text { mengganggu, desain } \\
\text { nyaman }\end{array}$ \\
& 3 & $\begin{array}{l}\text { Desain aplikasi menarik } \\
\text { dan nyaman }\end{array}$ \\
4 & $\begin{array}{l}\text { Aplikasi simpel dan } \\
\text { mudah } \\
\text { Aplikasi simpel, kreatif, } \\
\text { suara alat musik singkat } \\
\text { dan alat musik bisa } \\
\text { dipilih acak }\end{array}$ \\
\hline
\end{tabular}

Dengan demikian, kriteria-kriteria yang diinginkan pengguna yang disebutkan oleh responden menjadi acuan perbandingan antar aplikasi serupa dan menjadi pedoman pada aplikasi DOREMI yang dirancang bangun.

Setelah melakukan wawancara, proses selanjutnya adalah proses desain rancang bangun perangkat lunak. Penelitian ini menggunakan desain sistem model Unified Model Language (UML) dikarenakan model ini paling sesuai digunakan untuk mengembangkan sistem berorientasi objek.

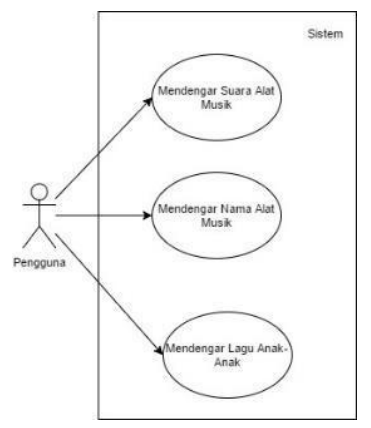

Gambar 2. Use Case Diagram

Setelah tahap Task Modelling, dilakukan dilakukan tahap prototipe yaitu pembuatan aplikasi melalui proses desain dan pengkodean sistem. Tahapan prototipe dilakukan dengan menggunakan metode prototyping.
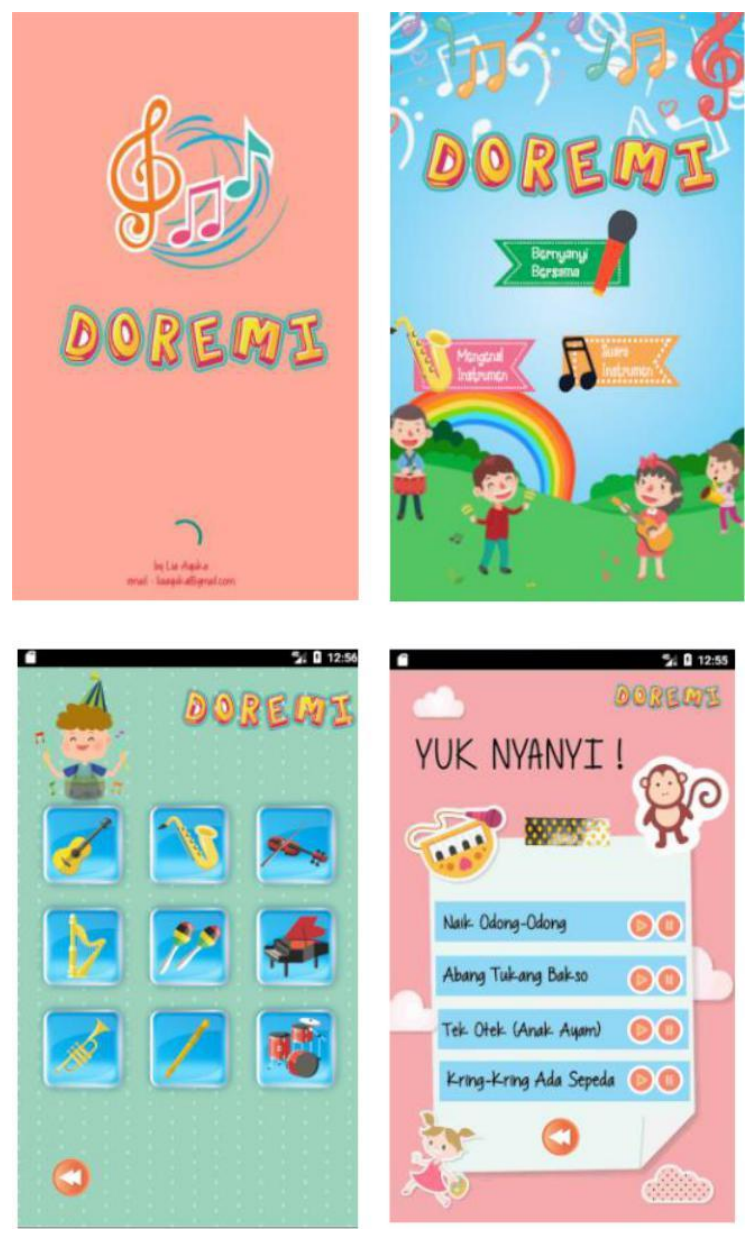

Gambar 3. Tampilan Aplikasi

\subsection{Pengujian}

\subsubsection{Pengujian White Box}

Metode pengujian white box adalah suatu metode desain test case yang menggunakan structural testing untuk memperoleh test case. Inti dari pengujian white box ini adalah menguji berdasarkan kesalahan ketika siap menguji semua objek di aplikasi dan semua metode eksternal atau publik dari objek.

Gambar 4. merupakan gambar urutan script yang diuji.

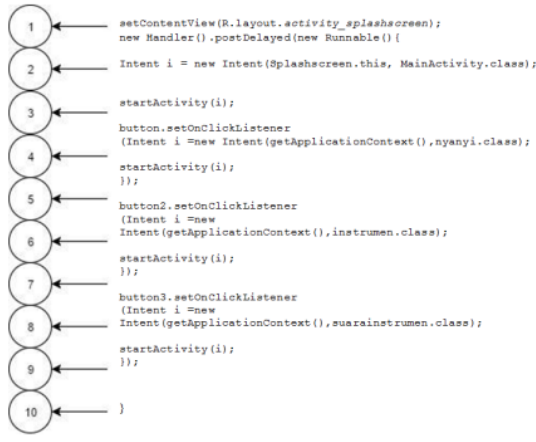

Gambar 4. Urutan Script 


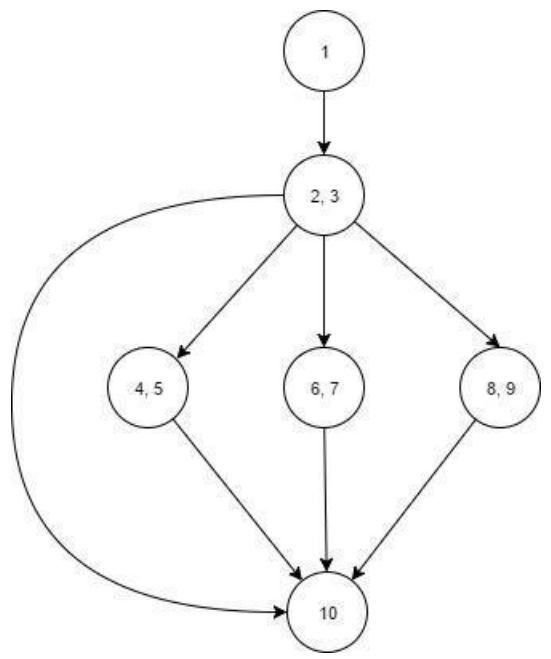

Gambar 5. Diagram Alir

Menghitung Cyclomatic Complexity: Kompleksitas siklomatis, pengukuran kuantitatif terhadap kompleksitas logis suatu program) dari grafik alir dapat diperoleh dengan perhitungan :

$$
\begin{aligned}
& \mathrm{V}(\mathrm{G})=\mathrm{E}-\mathrm{N}+2 \\
& \mathrm{~V}(\mathrm{G})=8-6+2 \\
& \mathrm{E}=\text { panah (edge) } \\
& \mathrm{N}=\text { lingkaran (node) }
\end{aligned}
$$

Berdasarkan hasil perhitungan tersebut, kompleksitas siklomatis yang dihasilkan adalah 4. Karena nilai tersebut kurang dari 10 berarti termasuk dalam algoritma yang tidak kompleks dan memenuhi kriteria rekayasa perangkat lunak.

Berdasarkan gambar 5 dan kompleksitas siklomatis dapat ditentukan independent path. Terdapat 4 (empat) independent path, yaitu :

Path $1: 1,2,3,10$

Path $2: 1,2,3,4,5,10$

Path $3: 1,2,3,6,7,10$

Path $4: 1,2,3,8,9,10$

Kemudian dilanjutkan dengan Value Test, yaitu menguji setiap independent path.

Tabel 4. Value Test

\begin{tabular}{llll}
\hline No Path & \multicolumn{1}{c}{ Input } & \multicolumn{1}{c}{ Output } & $\begin{array}{c}\text { Keterang } \\
\text { an }\end{array}$ \\
\hline 1 & $1,2,3$, & Menampilkan & Homepage \\
\multicolumn{1}{c}{10} & homercapai \\
& dengan & tampil \\
& sempurna & dengan \\
& baik \\
\hline
\end{tabular}

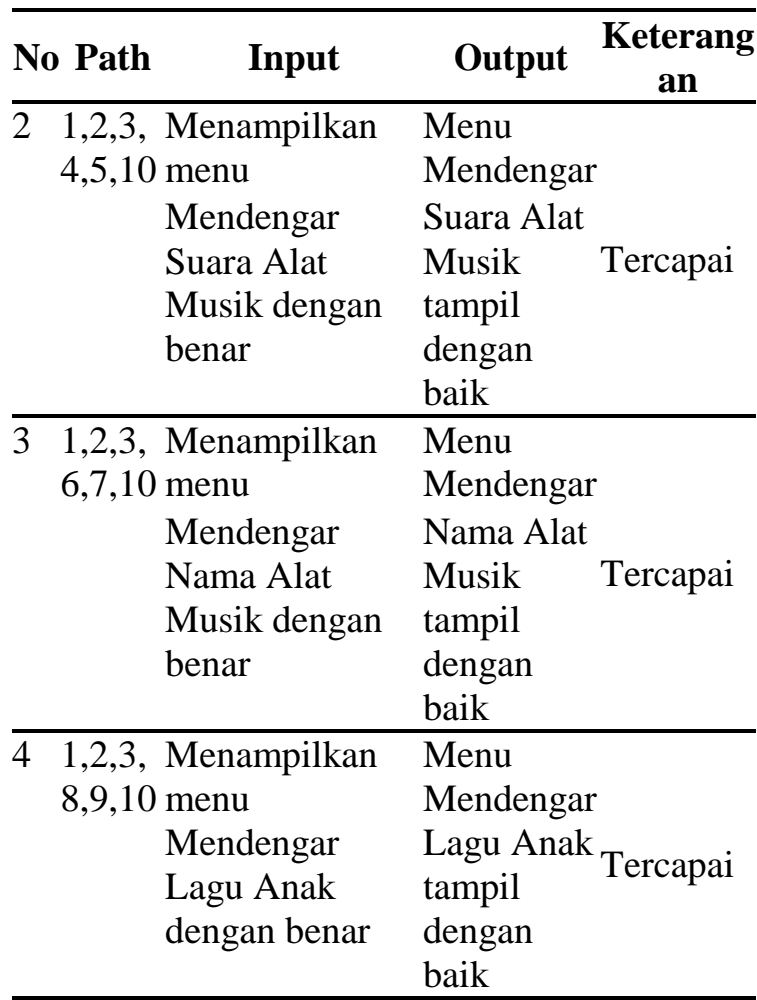

Pengujian white box dilakukan oleh programmer Aplikasi DOREMI. Berdasarkan hasil pengujian pada tabel, dapat diketahui presentase ketercapaian sebagai berikut :

Tercapai $=\frac{4}{4} \times 100 \%=100 \%$

Gagal $=\frac{0}{4} \times 100 \%=0 \%$

Setelah didapatkan nilai kuantitatif kemudian dikonversikan menjadi nilai kualitatif berdasarkan skala penilaian media. Maka hasil pengujian white box yang didapatkan adalah dengan interpretasi "Sangat Baik". Sehingga aplikasi dapat dilanjutkan dengan pengujian black box.

\subsubsection{Pengujian Black Box}

Black box testing adalah pengujian yang dilakukan hanya mengamati hasil eksekusi melalui data uji dan memeriksa fungsional dari perangkat lunak. Pengujian black box didasarkan pada use case yang telah dibuat.

Tabel 5. Hasil Pengujian Navigasi dan Konten

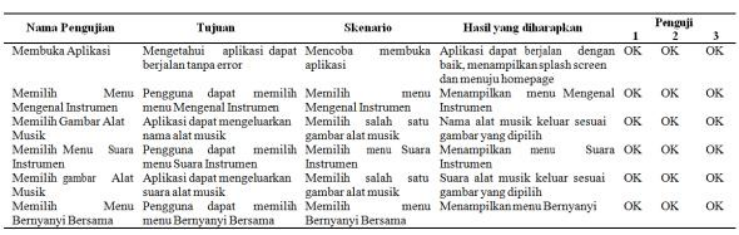


Berdasarkan hasil pengujian pada tabel 5, dapat diketahui presentase ketercapaian sebagai berikut :

Tercapai $=\frac{6}{6} \times 100 \%=100 \%$

Gagal $=\frac{0}{6} \times 100 \%=0 \%$

Setelah didapatkan nilai kuantitatif kemudian dikonversikan menjadi nilai kualitatif berdasarkan skala penilaian media. Maka hasil pengujian black box menunjukan interpretasi "Sangat Baik". Sehingga aplikasi DOREMI dapat diterapkan pada anak-anak usia 2-6 tahun di Indonesia.

\section{KESIMPULAN DAN SARAN}

Penelitian ini menghasilkan sebuah aplikasi pengenalan alat musik berbasis android yang dibangun berdasarkan kriteria yang diinginkan pengguna. Rancang bangun aplikasi DOREMI menggunakan tahapan dengan metode User Centered Design yang terdiri dari wawancara, task modelling dan prototyping. Kemudian dilanjutkan dengan pengujian menggunakan white box dan black box. Aplikasi DOREMI sebagai aplikasi pengenalan alat musik yang dilengkapi menu suara alat musik, nama alat musik, dan bernyanyi bersama.

Berdasarkan hasil penelitian ini, penelitian belum mencakup mengenai seberapa efektif aplikasi DOREMI untuk pengenalan alat musik pada anak usia 2-6 tahun. Sehingga penulis menyarankan perlu dilakukan penelitian lanjut di kemudian hari untuk mengetahui tingkat efektifitas aplikasi DOREMI untuk pengenalan alat musik pada anak usia 2-6 tahun. Kemudian, bagi penelitian selanjutnya agar dapat menambahkan beberapa alat musik lagi karena jumlahnya yang masih sedikit kemudian dikembangkan dengan menambah animasi pada saat alat musik dimainkan.

\section{DAFTAR PUSTAKA}

Oktaviani, R., (2014), Perancangan Media Interaktif Pengenalan Alat Musik Tradisional dan Modern Anak Usia 4-6 Tahun, ejournal BSI, vol. 1, p. 1.

Izzaty, R. E., (2013), Musik dan Perkembangan Anak, [Online]. Available: http://staff.uny.ac.id/sites/default/files/la in-lain/dr-rita-eka-izzaty-spsi-
msi/Musik\%20dan\%20perkembangan.p df. [Accessed 1112 2017].

Ardiansyah, W dan Sadikin, A, (2018), Perancangan Aplikasi Pengenalan Alat Musik Tradisional Nusantara Berbasis Android, Processor, vol. 12, p. 1012

Amborowati, A, (2010), Rancangan Sistem Pameran Online Menggunakan Metode UCD (User Centered Design), IST AKPRIND, p. 1.

Pratiwi, D. dkk, (2018), Penggunaan Metode User Centered Design (UCD) dalam Perancangan Ulang Web Portal Jurusan Psikologi FISP Universitas Brawijaya, Jurnal Pengembangan Teknologi Informasi dan Ilmu Komputer, vol. 2, pp. 2448-2458.

Haryanto, (2013), Aplikasi Pemesanan Barang Menggunakan Metode User Centered Design (UCD) Berbasis Android, Fakultas Ilmu Komputer UDINUS, 2009.

Khasani, S. R. I., (2017), Rancang Bangun Aplikasi Wisata Kuliner Berbasis Android Menggunakan Metode UCD, STMIK AKAKOM, pp. 7-10.

Safaat, N., (2012), Pemograman Aplikasi Mobile Smartphone dan Tablet PC Berbasis Android, Bandung: Informatika.

Garret, J. J., (2011), The Elements of User Experience: User-Centered Design for the Web and Beyond, Second Edition, California: New Riders.

Sukamto A. R dan Shalahudin, M., Rekayasa Perangkat Lunak(Terstruktur dan Berorientasi Objek), Bandung: Modula, 2011. 